\title{
$\longrightarrow$ TESTEMUNHO E A PRODUÇÃO DE VALOR MORAL: OBSERVAÇÕES ETNOGRÁFICAS SOBRE UM CENTRO DE RECUPERAÇÃO EVANGÉLICO
}

\author{
Cesar Pinheiro Teixeira \\ Universidade Federal do Rio de Janeiro - Rio de Janeiro \\ Rio de Janeiro - Brasil
}

André ${ }^{1}$ estava sentado na primeira fileira do pequenino templo do centro de recuperação. Visivelmente ansioso, entre aleluias e glórias a Deus, esfregava as mãos e balançava insistentemente as pernas enquanto acompanhava as primeiras oportunidades dadas no início do culto. Dias antes, comentara comigo que o pastor achava que ele já estava pronto para dar seu testemunho e que deveria fazê-lo o quanto antes. A ocasião havia chegado. André teria que contar àquela audiência - cerca de noventa homens - a sua história de pecados, de sofrimento e de transformação. Tudo ocorreu conforme o esperado: apesar da timidez, o rapaz narrou habilidosamente a saga que o levara até o centro de recuperação e a se engajar na construção de uma nova vida.

No entanto, ao mesmo tempo que se sentia honrado, André também se sentia receoso. Para ele, por um lado, o convite do pastor significava o reconhecimento de sua recuperação: estaria se tornando um exemplo para os demais - seu testemunho estaria sendo requisitado principalmente por essa razão. Mas, por outro, receber essa honraria também representava a necessidade de assumir um compromisso moral (com o pastor, com os demais alunos do centro, com sua família e com Deus) que o deixava ansioso e inquieto. "Agora eu vou ter que ser mais vigilante do que era antes, porque o diabo vai me tentar mais também, vai jogar ainda mais setas em mim". Com isso, André parecia indicar que dar seu testemunho era algo que incrementava o compromisso com o ideal de transformação que, conforme o convite que lhe fora 
feito, ele mesmo representava. "Porque dar o testemunho não basta, temos que ser testemunho da palavra de Deus todos os dias, o meu testemunho é a minha recuperação, é a minha mudança", dissera-me alguns momentos antes do início do culto.

Essa brevíssima cena é densa em termos de significados e de questões. Nela, o testemunho parece não se esgotar em seu conteúdo, isto é, seria uma prática que não se resume à construção política da memória e do passado capazes de ressignificar o presente e os horizontes de futuros possíveis ${ }^{2}$, embora seja atravessada por ela, evidentemente. O antropólogo Eduardo Dullo $(2011,2013)$, por exemplo, chama a atenção para possibilidades analíticas do testemunho que vão além da abordagem que põe no centro da análise a construção de uma narrativa biográfica. Dullo propõe uma teoria do testemunho na qual este seja pensado como uma ferramenta de agência na vida social, atentando para como os atores exploram sua dimensão psicagógica, isto é, o potencial pedagógico do testemunho, contido na exemplaridade de uma trajetória singular. Neste texto, inspiro-me nas observações críticas de Dullo em relação à centralidade do conteúdo nas análises sobre testemunho, embora não pretenda refletir especificamente a respeito dos efeitos sobre a audiência, e sim descrever os mecanismos sociológicos associados à prática do testemunho no contexto de um centro de recuperação, no qual sua construção se confunde com a própria ideia de "recuperação".

A cena de André sugere que no ato de testemunhar há um importante indicador moral, valioso àquele contexto: a possibilidade de dar o testemunho implica o reconhecimento de uma certa autoridade moral adquirida no processo de "recuperação". O testemunho é percebido como o principal signo da reconstrução moral de si que o centro de recuperação propõe realizar nas pessoas que por lá passam. No entanto, como ouvi algumas vezes durante o trabalho de campo, "não basta ter história de sofrimento pra contar, porque aqui todo mundo sofreu muito na vida". Ou seja, o testemunho não se limitaria ao relato em primeira pessoa que só o testemunhante pode dar. Mais do que isso, a construção do testemunho dependeria da capacidade do ator e da instituição em que se encontra de transformar a sua história de pecados em uma evidência de "transformação de si" e da possibilidade dessa transformação. Portanto, nesse contexto, pressupõe-se que a experiência em primeira pessoa, embora indispensável para a construção do testemunho, não é o que o define. A prática do testemunho iria além da construção de uma narrativa e da sua performance.

Aposto na ideia de que o testemunho pode representar mais do que a expressão de um processo, isto é, seria mais do que uma variável dependente, explicada por mecanismos mais amplos. Meu objetivo é levar a sério o testemunho e a recuperação da qual ele seria o indicador, a fim de entender os mecanismos sociológicos intrínsecos a essa prática, vista como capaz de produzir e de agregar valor moral aos atores socialmente desacreditados que povoam o centro de recuperação. Nesse sentido, o propósito é compreender como o centro de recuperação pode fazer sentido para os atores, procurando abrir a caixa preta da recuperação, com o intuito de entender, em suma, o que o centro recupera e como o faz. Minha hipótese é a de que o testemunho 
possui um lugar central nesse processo, não só como fonte de dados sobre a trajetória dos atores, mas também por ser um mecanismo sociológico em si mesmo, através do qual os atores podem ganhar ou perder valor moral.

De acordo com a lógica em jogo no contexto do centro de recuperação, as histórias de sofrimento e decadência, por si só, não constituem um testemunho. E, por isso, haveria então uma distância entre "ter um testemunho" (no sentido de ter uma história para contar) e "dar o testemunho" (performatizá-lo, contá-lo a alguma audiência). Essas duas dimensões do testemunho seriam mediadas por uma terceira, geralmente sintetizada na ideia de "ser testemunho", que diz respeito à vivência cotidiana da transformação que é apresentada na narrativa. Geralmente, as pessoas reconhecidas como as que se esforçam para "ser testemunho", dando provas de sua transformação no cotidiano do centro, são as escolhidas pelas lideranças para performatizarem publicamente seus testemunhos em cultos e outros eventos realizados naquele local. De certo modo, a transformação de si proposta no centro passa justamente pela transformação de uma trajetória decadente em um testemunho, processo através do qual se "resgata a dignidade perdida" e se "ganha valor moral". Nesse sentido, o objetivo do centro de recuperação é justamente produzir testemunhos, como na história de André. Ou seja, nesse contexto, o testemunho em sua dimensão performativa só é visto como adequado quando o testemunhante é considerado minimamente pronto para tal. Como isso ocorre?

Para explorar essa questão, mobilizo dados produzidos no contexto de minha pesquisa de doutorado (Teixeira 2013), em um centro de recuperação evangélico localizado na periferia urbana do Rio de Janeiro ${ }^{3}$. O material empírico consiste em entrevistas com ex-bandidos ligados diretamente ao narcotráfico varejista presente em favelas e periferias do Rio, bem como em situações e interações que esses e outros atores protagonizam no cotidiano do centro. Como veremos, essas pessoas passam por um processo de decadência moral que os conduz ao centro de recuperação. Lá buscam reconstruir suas vidas, "recuperando a dignidade perdida", transformando sua decadência em testemunho. De forma geral, minha ideia não é descrever a construção dos sujeitos a partir de seus testemunhos, isto é, não pretendo descrever como os "recuperados" produzem os seus testemunhos. Ao contrário, o objetivo é entender a forma através da qual a prática do testemunho pode produzir o "recuperado".

\section{O centro de recuperação}

O contexto é um centro de recuperação evangélico situado em uma cidade da periferia da região metropolitana do Rio de Janeiro, que recebe pessoas com trajetórias significativamente distintas. "Dependentes químicos", "moradores de rua", "ex-presidiários", "pessoas que querem largar o crime", "pessoas juradas de morte por traficantes ou milicianos", entre outros casos menos comuns, compõem basicamente a população que convive no sítio onde funciona o centro de recuperação. Seu líder e 
fundador, o pastor Vladimir, era mecânico e morava em um bairro suburbano carioca. "Ex-viciado", a história do pastor é marcada por ter "se libertado das drogas" através da conversão. Vladimir era um fiel da Assembleia de Deus. Pastoreou algumas igrejas ao longo de sua vida. Mas rompeu suas ligações com a igreja e passou a trabalhar de forma independente, no centro de recuperação. Entretanto, a dinâmica de funcionamento do centro é extremamente semelhante à que ocorre em diversas Assembleias de Deus. Como ouvi de Vladimir algumas vezes, "decidi deixar de ser pastor de igreja pra ser apenas pastor no centro de recuperação".

À época da pesquisa, o centro de recuperação dividia-se em algumas "casas" espalhadas pelo estado do Rio de Janeiro: umas só para mulheres, outras só para homens. Meu trabalho foi desenvolvido em uma casa masculina. Trata-se de um sítio com espaço amplo e que, na ocasião em que o frequentei, abrigava pouco mais de cem homens, chamados de "alunos" (termo designado para se referir aos internos e que enfatiza a dimensão de aprendizagem da experiência). De acordo com o pastor, os alunos devem permanecer no sítio por nove meses (metáfora explícita do "novo nascimento") para completarem o chamado processo de recuperação. Mas, embora isso seja apresentado como procedimento padrão, o tempo de permanência pode variar bastante conforme cada caso em particular.

A vida no centro de recuperação representa uma experiência intensa de engajamento na "vida evangélica". Contudo, é necessário destacar que a maior parte das pessoas que recorrem ao centro já são evangélicas, no sentido de que partilham da fé cristã pentecostal de antemão. Ou seja, para a maior parte das pessoas que chegam ali, as metáforas, as narrativas, os conceitos, as imagens e todos os recursos simbólicos do repertório pentecostal não representam uma novidade. Aliás, é justamente por já operar com eles que muitas pessoas decidem "recuperar-se" naquele local e daquele modo.

As diversas trajetórias e personagens que compõem o centro podem ser agrupadas em três tipos sociais: o "mendigo", o "viciado" e o "vacilão". Estes, por sua vez, nos servem como instrumentos analíticos importantes, visto que nos auxiliam na tarefa de compreender com mais clareza a complexidade das relações, das interações e das situações que se desenrolam no cotidiano do sítio. Evidentemente, essas categorias não necessariamente dividem as pessoas; uma mesma trajetória pode conter - e não é raro que isso aconteça - as três possibilidades.

O mendigo - ou morador de rua - representa, para os alunos, o grau máximo de desfiliação (Castel 1997) - e, por isso, de sofrimento e de decadência - a que uma pessoa pode chegar". Sua situação é descrita como o "fundo do poço". Trata-se da pessoa que já não possuiria contato com familiares, que não trabalha e que precisaria recorrer à solidariedade alheia para sobreviver. $\mathrm{O}$ mendigo pode chegar ao centro de recuperação de diversas maneiras, mas geralmente é trazido por outras pessoas quase sempre crentes que fazem serviços de evangelização junto a moradores de rua e os convencem a se recuperar em casas como a que estudamos aqui. Em geral, são pessoas na faixa dos 50 anos de idade e que possuem diagnóstico de alcoolismo. Por 
isso, muitas vezes alguns alunos também mobilizavam a categoria "cachaceiro" para se referir àqueles que possuem esse tipo de trajetória. A maior parte dos ex-mendigos, principalmente os mais velhos, permanece no sítio por tempo indefinido, reconstruindo ali mesmo as suas vidas. Ou seja, para muitos deles o centro de recuperação não é um local de passagem; é um ponto de chegada. Há alguns que estão no sítio desde que o pastor Vladimir iniciou o seu trabalho, há mais de dez anos.

O viciado - ou dependente químico - é aquele que procura o centro de recuperação exclusivamente por conta de sua "dependência" do uso de drogas ilícitas (quase invariavelmente: crack, cocaína, maconha). $O$ viciado é alguém que possui trabalho, muitas vezes no mercado formal, e mantém vínculos familiares e afetivos. Diferentemente do mendigo, ele não é visto como um completo dependente da solidariedade alheia. No entanto, seu "vício" faz com que ele se torne uma "pessoa problemática" nos círculos sociais nos quais se encontra inserido. Muitas vezes ele perde o emprego, é abandonado pela família e pelos amigos - e em muitos casos acaba se tornando um mendigo. O viciado, em geral, é conduzido ao centro de recuperação por familiares ou amigos e busca "curar seu vício" a fim de reconstruir os laços sociais desfeitos ou seriamente comprometidos. Não é raro que o viciado seja um bandido que "perdeu o controle" sobre o uso da droga e teve sua vida no "movimento" prejudicada por conta disso. $\mathrm{Ou}$, como ocorre em outros casos, é alguém que aposta no tratamento de sua "dependência" como uma forma de romper definitivamente com o "mundo do crime", uma vez que associa uso de drogas e envolvimento com o tráfico. De modo geral, os viciados são pessoas jovens que permanecem no sítio o tempo necessário (que, como disse anteriormente, varia de caso para caso, embora haja uma estimativa média, por parte do pastor Vladimir, de nove meses) para serem consideradas "recuperadas" e partirem para a reconstrução da vida que fora prejudicada pelo "vício".

Vacilão é uma categoria que guarda o sentido que lhe é atribuído no contexto do "mundo do crime" no Rio de Janeiro: é a pessoa que fere a "ética do certo" (Grillo 2013; Freitas 2016), cometendo algum tipo de ato considerado desviante (como estupros, roubos e furtos em favelas ocupadas por grupos de narcotraficantes ou milicianos, ou que comete desvios no interior de quadrilhas às quais pertence) e que, por isso, é ameaçada de morte pelos bandidos. É exclusivamente desse modo que o vacilão se torna um desfiliado: sem poder permanecer na área onde mora, perde os vínculos sociais através dos quais consegue sustentar a sua vida. Muitos deles também se tornam moradores de rua. Na maioria das vezes, familiares desesperados recorrem aos centros de recuperação para que seus parentes não sejam torturados e mortos por traficantes ou milicianos. Noutras ocasiões, os próprios bandidos recomendam que os vacilões sejam encaminhados para centros de recuperação. Nesses casos, eles entram em contato com os responsáveis pela casa, geralmente pastores que atuam em suas favelas, e pedem para que estes busquem os infratores locais. Além disso, também é bastante comum que os pastores sejam chamados a interceder por alguns rapazes em situações nas quais eles já se encontram prestes a ser assassinados. Escutei diversas histórias do 
pastor Vladimir, em que relata como conseguiu resgatar pessoas prestes a morrer. $\mathrm{Na}$ maior parte das vezes, os vacilos cometidos são diretamente associados à "dependência química", isto é, acredita-se que os vacilões agem do modo que agem porque são "viciados". É importante ressaltar que o uso de crack é constantemente associado a esse tipo social. Lembro-me de uma conversa com um ex-bandido, no próprio centro de recuperação, na qual ouvi uma frase lapidar quando falávamos do "problema do crack" na favela onde morava: "o crack é uma fábrica de vacilões". Assim, a diferença básica entre o vacilão e o viciado, como tipos sociais que povoam o centro de recuperação, é que o vacilão pode ser um viciado, mas um viciado não é um vacilão.

No centro de recuperação, os próprios alunos assumem as responsabilidades pela organização interna. Lá eles encaram uma intensa rotina religiosa (cultos, orações diárias, louvores, estudos bíblicos, etc.) e uma intensa rotina de tarefas internas (como realização de pequenas obras e reformas no próprio sítio, trabalhos de limpeza, de cozinha, entre outros). Não há técnicos: assistentes sociais, psicólogos, pedagogos, nem mesmo seguranças ${ }^{6}$. Toda a organização da casa fica a cargo dos próprios alunos, além do pastor. $\mathrm{O}$ pastor seleciona alguns (em geral, os mais antigos) para ocuparem pequenos cargos de confiança, no qual assumem certas responsabilidades. Esses não são chamados de alunos, embora também o sejam, e sim de obreiros. Os obreiros representam a autoridade na casa quando o pastor está ausente - o que não é raro, já que o pastor administra várias casas de recuperação. As tarefas são múltiplas: eles são responsáveis por presidir os cultos diários, receber e orientar os recém-chegados, organizar os internos na hora das refeições, dividir e administrar as tarefas cotidianas, etc. Evidentemente, conforme os alunos saem do sítio, as pessoas que ocupam esses "cargos" vão sendo substituídas. No entanto, um dos alunos, chamado Raimundo, adquiriu a confiança do pastor Vladimir a ponto de ser convidado para juntar-se a ele, ocupando um lugar que poderia ser descrito como o de "braço direito" do líder. Raimundo também é chamado de pastor pelos demais e se reveza com Vladimir nas tarefas religiosas e administrativas consideradas de maior importância.

Abaixo dos obreiros, estão os alunos responsáveis por diversas tarefas relevantes na rotina do centro de recuperação: os cozinheiros, os responsáveis pelo dormitório, os porteiros, dentre outras atividades. Os demais alunos se revezam cotidianamente em diferentes tarefas, como cuidar dos animais, limpar os aposentos, trabalhar nas obras internas, realizar serviços de capinagem, etc. Há que se destacar que há uma modesta produção de vassouras no sítio - que representa uma fonte de renda secundária. Os alunos produzem as vassouras e depois saem pela cidade vendendo-as e divulgando o trabalho do centro de recuperação. De modo geral, ser nomeado para ocupar esses cargos é considerado, simultaneamente, uma forma de recuperar e um indicador da recuperação de alguém. Por exemplo, apenas os alunos considerados aptos para irem às ruas é que podem se tornar vendedores de vassouras. Ao mesmo tempo, ir para as ruas vender as vassouras é uma oportunidade para dar provas de sua recuperação e construir seu testemunho. 


\section{A “matéria-prima” do testemunho: trajetórias de decadência moral}

A maior parte das histórias de vida das pessoas que estão no centro de recuperação narra trajetórias de decadência moral, isto é, trajetórias nas quais os atores descrevem um processo progressivo da perda de seu valor como pessoa, de sua "dignidade". A construção do testemunho passa tanto pelo reconhecimento dessa decadência como pelo investimento em modos de conduta entendidos como necessários para sua superação. No entanto, neste contexto, o testemunho não se esgotaria na construção de uma narrativa que busca traduzir em palavras uma experiência subjetiva de dor e de sofrimento (Das 2007). No centro de recuperação o testemunho não se encerraria no ato de testemunhar (Das 2011). Ou, pensado de outro modo, o ato de testemunhar não se esgotaria na construção de uma narrativa biográfica e em sua performance. Ali, a construção do testemunho parte dessas trajetórias decadentes, que são amplamente compartilhadas pelos alunos, e que consistem em dramas pessoais atravessados por conflitos associados ao uso de drogas, ao tráfico de drogas nas periferias urbanas, por questões religiosas, entre outros marcadores. Assim, para podermos entender os mecanismos através dos quais a decadência é transformada em testemunho, é preciso descrever alguns detalhes dessas trajetórias que funcionam como "matéria-prima" para a construção do próprio testemunho. Antes, porém, é necessário sublinhar que "decadência" não consiste apenas em um julgamento realizado a partir dos valores religiosos da "nova vida". Como veremos, trata-se de algo que é compartilhado de forma ampla, inclusive por aqueles que se encontram no "mundo do crime". Na maior parte dos casos, a "saída do crime" não foi narrada como um processo que insere, imediatamente, o ex-bandido em uma vida considerada moralmente positiva. Ao contrário, o rompimento com o crime pode ser interpretado como a consequência de uma trajetória de decadência moral ou como o início dela.

Para explorar essas questões, trago três episódios que nos oferecem um bom panorama da complexidade em jogo, embora certamente não esgote as possibilidades empíricas. De forma geral, esses três casos nos ajudam a esclarecer como os atores chegam ao centro de recuperação, onde procuram transformar suas histórias em testemunhos, os quais podem ser ou não, posteriormente, performatizados.

Cleiton entrou para o crime bastante novo, com apenas 12 anos de idade. Foi "fogueteiro", "vapor", "gerente" e, antes de romper, havia sido o "frente da favela" em que morava. Ele desfrutava de uma boa vida no crime: conta que chegou a ganhar cerca de dois mil reais por semana. Com o dinheiro, sustentava sua mulher e seus sete filhos; tinha acesso a bens materiais considerados luxuosos; possuía o respeito dos amigos. Quando descreve sua vida no crime, o rapaz apresenta um cenário de conquistas das quais se mostrava bastante orgulhoso. No entanto, relata também um episódio de traição que modificara consideravelmente a sua vida.

Quando entrou para o crime, a favela em que Cleiton morava possuía apenas uma facção. Contudo, um desentendimento entre as lideranças provocou uma fratu- 
ra no movimento local, que acabou dividido em duas facções rivais. De modo muito repentino, Cleiton viu-se como inimigo de parentes e amigos, bem como de colegas de ofício, que decidiram se aliar ao lado oposto ao qual ele se encontrava. Em sua narrativa, o rapaz descreve isso como um primeiro grande abalo em sua trajetória. De todo modo, Cleiton permanece no crime e vai acumulando prestígio junto aos amigos e às lideranças da facção em que escolheu ficar, sobretudo por conta da sua disposição para "trocar tiro com a polícia" e para matar vacilões e inimigos em geral. Ele sublinha que boa parte de sua "moral no crime" fora conquistada matando.

Aos poucos Cleiton conquista a confiança de seu patrão, chegando a ocupar o posto de "segundo homem", responsável por toda a administração do movimento também chamado de "frente da favela" quando o "dono" se encontra preso. No entanto, nesse período de sua vida, o irmão do patrão de Cleiton, que também compunha a quadrilha, articula um golpe com outros membros: queria desbancar o irmão preso e se tornar o líder daquela facção naquela favela. Porém, Cleiton permanece fiel ao seu patrão. Estoura uma nova guerra no interior da facção. Cleiton sai derrotado e vê-se em uma situação extremamente complicada. Não poderia permanecer na favela, pois, conforme conta na entrevista, "estava mais pedido que nota de um real". A vida no crime havia the proporcionado muitas inimizades: ele era procurado por pessoas de facções rivais, pelos membros da sua facção que articularam o golpe e pela polícia. Ele não poderia permanecer em sua favela e não tinha para onde ir. A partir daí sua vida se torna uma peregrinação. Ele chega, inclusive, a trabalhar como segurança para um grupo de milicianos estabelecido em um bairro periférico de uma cidade vizinha. Mas diz que jamais conseguira recuperar a vida que havia conquistado no movimento. Diz que, cada vez mais pobre e deprimido por estar longe da família e dos amigos, já não tinha dinheiro para comprar drogas e, então, começa a beber cachaça - o que, para ele, é um forte indicador de sua decadência moral. Até que foi parar nas ruas.

Ali eu vi como era a situação de um mendigo. Eu nunca pensei em passar por isso na minha vida. Desespero. Você teve de tudo. Você trabalhou pro mal. Você acabou com a tua família. Você acabou com a vida da tua mãe, tava deixando tua mãe doente. Teu irmão querendo te ajudar e você não tava nem ali pra ele. E você jogado na rua é uma coisa que eu nunca mais quero passar na minha vida não. Comendo lixo de rua. Comendo resto dos outros. Pedindo o dinheiro dos outros. Mas eu nunca roubei ninguém na rua. Eu sou mais de pedir do que de roubar. É sofredor demais. Aí eu decidi mudar. Mas ali mesmo satanás tava jogando na minha cara, dizendo que era pra eu entregar meus pontos e me matar. Aí tinha um viaduto ali atravessando a cidade, eu andei tudo e pensei: é dali que eu vou me jogar. Satanás jogando seta... e aí veio aquele vento que toca no coração: não faz isso não, dá uma chance pra você mesmo. Satanás tá jogando seta pra você querer se matar. Você 
olhando pra trás e... perdeu tudo, não tem mais nada não, se mata, pô. Aí chegou um senhor lá e falou comigo e eu perguntei pra ele assim: moço, como é que eu faço pra mudar de vida? Ele perguntou: como você quer mudar de vida? Eu falei: olha pra minha situação moço, eu não tenho nada; eu tinha tudo, trabalhei pro mal e agora não tenho nada. Aí esse rapaz chegou pra mim e falou assim: você aceita Jesus como seu único salvador? Eu falei: aceito. [...] Aí encontrei um pastor, que falou comigo assim: aguarda um tempo aí que eu tenho que falar com o [outro] pastor - e eu não sabia que era o pastor Vladimir. E eu fiquei dormindo na porta da igreja e todo dia que ele me via de manhã ele falava: calma aí que daqui a pouco tu vai [para o centro de recuperação]. Aí eu falei: eu não tô aguentando mais, pastor, eu quero me matar. Ele falou: não faz isso não. Eu falei: eu não aguento mais, eu tô com fome. Aí ele: calma aí que eu vou te dar comida. A esposa dele me deu dez reais, eu botei no bolso. Fumei uns cigarros, mas nem o cigarro tava ajudando. Minha vontade era de me matar. Aí ele me botou dentro do carro dele. E eu falei: como é que eu vou entrar dentro do carro do senhor, pastor, que eu tô fedendo. Eu tô aí dormindo nesse chão há vários dias. As pessoas tratam você que nem bicho. Você chega pra pedir e as pessoas saem correndo de você. E você se sente mal. Aí eu conheci o pastor Vladimir lá na favela [uma das casas que ele administra fica lá], onde eu fiquei um bom tempo no tráfico. Aí eu falei, eu tenho uma rixa aqui dentro desse lugar. Aí o pastor me trouxe pra cá [para outra casa].

Em trajetórias como a de Cleiton, é justamente a decadência moral oriunda do rompimento com o "mundo do crime" que conduz à conversão, ao engajamento na "vida evangélica". É a partir dela que Cleiton começa a narrar a sua vida no crime como algo "maligno" que o havia conduzido àquela situação de decadência: teria então "trabalhado para o mal" e por isso havia perdido tudo. Aqui, as ferramentas simbólicas do pentecostalismo ajudam-no a justificar a sua trajetória de decadência ao mesmo tempo que lhe indicam o caminho de sua recuperação. Em outros momentos da entrevista, ele nos conta que gostava de ir a alguns cultos, mas que nunca havia pensado em abandonar sua vida no crime para tornar-se evangélico. A conversão religiosa só se transformou em uma opção concreta quando o seu "mundo" desmoronou e ele já não conseguia reconstruir o que havia conquistado antes. De acordo com a narrativa, para sair do "fundo do poço", Cleiton necessitava mudar radicalmente de vida. Mesmo que as crenças pentecostais fizessem sentido para ele, enquanto ainda estava no crime, é apenas na sua fase decadente que o engajamento na "vida evangélica" se torna uma alternativa concreta.

Lucas possui uma história similar. Esse rapaz tinha uma trajetória de sucesso no crime, tendo conquistado dinheiro, poder, respeito e admiração dos amigos - so- 
bretudo pela sua disposição para o confronto e para a utilização da violência física. Contudo, diferentemente da história de Cleiton, seu rompimento com o "mundo do crime" está ligado aos impactos que as dinâmicas de violência produziam em sua subjetividade. Deixemos que ele mesmo nos conte um pouco de sua trajetória.

Minha diversão era enfrentar a equipe rival. Eu tava ali pra se divertir. Mas mesmo assim jogando a minha vida fora também, porque a qualquer momento eu poderia levar um tiro. Alguém poderia me pegar, me esquartejar, qualquer hora eu poderia sofrer alguma coisa. Minha família pediu pra que eu viesse a sair dessa vida. Porque eu já tava me aprofundando de uma certa forma que já não tava mais respeitando mais ninguém. Meu negócio era... eu só queria saber de ir pra guerra. Eu já tava sério. Eu tava num certo ritmo que era só guerra... eu só queria ver sangue. Tinha uma certa parte de cobrança que eu tinha que matar pessoas. Então aquilo já estava bagunçando a minha mente. Tinha parte da noite, quando eu dormia que eu acordava vendo as pessoas... que eu próprio tinha matado as pessoas. Aí minha família veio e pediu pra que eu viesse a sair daquela vida, porque se eu saísse daquela vida eles poderiam me ajudar. E eu disse que eu aceitava. Aí eu falei com o patrão e ele falou: ó Lucas, tá liberado; até porque seu padrinho mesmo tava quase pedindo pra você sair porque você tava se aprofundando de uma forma muito séria. Na verdade eu tava num certo ritmo que de um tempo pra cá eu entrei num centro psiquiátrico e tudo. Eu tava tão acelerado que eu mesmo queria me matar. Eu quis me matar. Teve um certo tempo que eu mesmo não estava aguentando mais minha própria vida. $\mathrm{O}$ que mais me doeu foi a perda da minha ex-mulher. Porque ela não queria me ver no tráfico e eu não conseguia largar.

Lucas rompe com o crime para tentar sair do "ritmo acelerado" que sua vida havia tomado - e também com a intenção de reconquistar sua ex-mulher, que o havia deixado por conta da forma intensa como ele vivia o crime. Conforme a narrativa, após a separação ele também se "aprofunda" no uso de drogas, fato que é interpretado como mais um sinal de decadência, como perda do controle sobre suas vontades. A partir daí, sua vida torna-se cada vez mais difícil e, assim como Cleiton, Lucas também chegou a parar nas ruas.

Eu tava querendo largar a droga, o crack, a cocaína, tá entendendo, o ecstasy. Eu fui se esforçando, se esforçando, mas mesmo assim eu não conseguia. E foi onde eu tava me aprofundando. Minha família me abandonou, fechou as portas pra mim. E eu fui morar na rua, igual a um mendigo. Comendo comida do lixo, resto de comida das outras pessoas. 
E eu tinha tudo na minha mão. Depois que eu larguei tudo, aí que a minha vida se aprofundou de vez.

Contudo, a reputação de Lucas no tráfico não havia sofrido qualquer abalo significativo por conta de seu "ritmo acelerado". Ao contrário, o rapaz assinala que isso era uma característica que o mantinha próximo ao "mundo do crime". Foi convidado para retornar ao movimento quando seus amigos souberam que estava nas ruas. Sem maiores alternativas, ele até tenta retornar ao crime, mas acaba desistindo: "Eu já tava tão bom na área do tráfico, que alguns não queriam que eu saísse. Eu cheguei a voltar, mas só fiquei uns dez dias e depois saí de novo. Aí eu já não queria mais ficar mesmo”.

Lucas era umbandista nessa época e participava ativamente no terreiro que frequentava. No entanto, o rapaz começa a realizar interpretações pentecostalizadas de seu passado (Birman 2009), associando suas antigas crenças com o mal considerado responsável pela sua decadência moral. Quando eu o conheci, já não era a primeira vez que passava pelo centro de recuperação. Sua conversão havia acontecido alguns anos antes, quando esteve no sítio pela primeira vez. No trecho abaixo, ele conta como decidiu se tornar evangélico.

Eu senti dentro de mim que eu tinha que mudar. Porque desde quando eu tava servindo a outros deuses, eu tava servindo a parte de umbanda, eu não tava sendo feliz. Tava com dinheiro, tava ganhando muito dinheiro, quem bate tambor ganha um dinheiro, e eu batia tambor pra três santos diferentes. Então eu ficava a noite toda. Tinha dia que eu ficava três, quatro dias, tinha que dormir dentro do terreiro pra que aquela festa viesse a continuar, porque eu é que dava o início da festa. Mas eu não tava sendo feliz, não tinha espaço pra mais nada. Minha vida era só aquilo. Tinha dia que eu tava cansado, mas eu tinha que continuar. Eu senti um certo poder diferente no meu corpo, porque quando o pastor me orou eu recebi uma certa entidade no meu corpo e aquela entidade, quando o pastor expulsou ela de mim, eu me senti diferente. É como eu tinha falado antes: antes eu tava cego e aí eu passei a enxergar. Quando eu passei a enxergar eu vi onde é que eu tava entrando, onde é que eu tava me afundando. Porque cada culto eu tinha que fazer um corte, dar sangue pra aquela certa entidade, aquele certo espírito, eu tinha que cumprir com as obrigações, senão eu era cobrado. No tráfico era cobrança, no terreiro era cobrança, então eu tava sempre apertado em áreas diferentes.

Lucas constrói ligações muito estreitas entre suas obrigações na umbanda, sua rotina no tráfico e a dinâmica de cobranças que o levou a romper com o "mundo do crime", lançando-o em uma trajetória de decadência moral. É diante desse quadro 
tão complexo que a ida para o centro de recuperação se torna, para Lucas, uma opção que realmente poderia provocar transformações positivas em sua vida.

Eu batia tambor pra uma certa entidade e essa certa entidade é que protegia o dono da favela. Então eu tava ali preso naquele sistema, tanto no tráfico quanto na parte de umbanda. Tem uma coisa que eu trago comigo até hoje. Que foi um sonho... um sonho não, foi realidade, mas eu sonho com isso até hoje como se eu tivesse fazendo novamente. Eu tava lá fazendo um certo ritual, então a entidade pediu uma criança como oferenda. Então eu tive que realizar aquele trabalho. Tive que pegar a criança e sacrificar a criança pra entregar pro santo. Aquilo ali marcou a minha vida. Eu fiz outros tipos de coisa, mas aquilo ali foi o mais marcante. Tinha momentos em que eu parava num bar, pra poder usar uma droga e conversar com os amigos e eu começava a chorar porque aquilo ali foi muito forte. Tem certas vezes no meu sonho que isso me perturba no sonho.

A ida para o sítio aparece como uma solução possível, uma forma para fazer com que Lucas interrompa a trajetória de declínio moral que, de acordo com a narrativa, o levou a se tornar um mendigo. As interseções entre suas antigas crenças e práticas religiosas e os valores e práticas do "mundo do crime" otimizavam o poder que a explicação pentecostal oferecia para sua trajetória decadente. Diante desse quadro, era preciso "mudar de vida", engajar-se completamente em algo que fosse capaz de resgatar a "dignidade perdida". E é justamente no "evangelho" que Lucas reconhece essa possibilidade. Decide, por isso, recuperar-se no centro do pastor Vladimir.

Pedro era um assaltante que atuava nas margens do "mundo do crime". Fazia bastante dinheiro assaltando bancos e carros-fortes, mas, por morar próximo a uma favela onde havia movimento, tornara-se amigo dos traficantes, compartilhando um pouco do seu estilo de vida e de seus valores. No entanto, Pedro morava no subúrbio, possuía emprego regular (era cobrador de ônibus) cuja renda lhe permitia sustentar sua mulher e seus filhos. Em certo momento de sua trajetória, decide experimentar o crack. Conta que achava o crack perigoso, mas que queria usar apenas para emagrecer. Porém, "perde o controle" e, a partir disso, conforme a narrativa, sua vida tornase também decadente. Pedro, outrora assaltante respeitado junto aos traficantes que conhecia, aos poucos se vê como alguém muito próximo do vacilão - capaz de roubar pessoas da própria família a fim de "saciar seu vício".

E minha vida acabou foi nessa aí mesmo, varão, nisso aí de fumar crack. Minha história me afetou dentro de casa. Eu cheguei a prejudicar muito a minha família. Na última vez eu prejudiquei uma prima minha que amo muito e pretendo chegar lá e pedir perdão e dar a ela o que eu tirei 
que foi um laptop. Satanás é tão astuto, usando tanto da minha vida, que meu primo, que eu também amo demais aquele cara, ele teve na minha casa, eu já astuto, já tinha tudo estudado pra falar com ele, minha esposa me perguntou se tinha sido eu [que havia roubado o laptop], eu e minha família fomos passear no shopping, trouxe alegria pra minha família... no crime eu já não tava mais... já não tava mais naquela vida de assaltante... mas tava roubando pequenas coisas perante a minha família. O crack te leva a fazer isso. $\mathrm{O}$ crack quebra o teu caráter. As pessoas na rua olhavam pra mim e falavam... pô, aquele cara é cracudo. Aquilo me doía muito mais que... perdão meu Pai... que eu tá num banco assaltando e ser preso. Eu acho que se eu tivesse num banco assaltando... perdão meu Pai... aquilo seria muito mais bonito pra mim.

Para Pedro, ter se tornado um "cracudo", capaz de roubar os próprios parentes, era um ato que indicava um grau extremo de decadência moral. Para ele, ser preso ao tentar roubar um banco representava algo muito mais digno que ser reconhecido como cracudo pelas pessoas. Os valores relacionados ao "mundo do crime", sobretudo ao associarem o cracudo ao tipo social vacilão, faziam com que Pedro se sentisse decadente. E, curiosamente, é a partir dessa aritmética moral que ele, então, opta pela ida para o centro como uma forma de recuperar a dignidade que, conforme sua narrativa, o "vício" lhe teria retirado.

As histórias de Cleiton, Lucas e Pedro esclarecem como os atores experimentam e significam a decadência moral que faz com que eles procurem a recuperação oferecida no centro do pastor Vladimir. No entanto, isso não constitui por si só o testemunho. No centro, ao buscarem resgatar a "dignidade perdida" é que eles o constroem. Nas próximas seções, trago algumas observações referentes ao cotidiano do centro de recuperação que procuram esclarecer as condições de possibilidade da potência associada à figura do "resgatado" e ao seu testemunho (Machado 2014). Assim, descreverei um pouco das maneiras como os atores transformam sua decadência em testemunho - o que significaria um processo de ascensão moral.

\section{Transformando a decadência em testemunho I: a palavra como técnica de recu- peração}

"Só a palavra pode recuperar as pessoas", disse-me o pastor Raimundo, em uma das minhas primeiras visitas ao sítio, batendo com a mão espalmada sobre uma bíblia grande e surrada. Para as lideranças do centro, a transformação esperada está diretamente relacionada ao contato com a "palavra de Deus". Evidentemente, essa não foi a primeira vez que escutei uma afirmação desse tipo e, por isso, a princípio, não me surpreendi. Contudo, aos poucos fui percebendo que, no contexto da pesquisa, essa não era uma informação trivial; ela era a porta de entrada para a compre- 
ensão de muitas situações que ocorriam no cotidiano do lugar. No entanto, a representação sugerida pelo pastor Raimundo, associando a palavra à bíblia, pode ser um pouco limitada. A palavra não é apenas um conjunto de livros considerados sagrados. No centro de recuperação a palavra era considerada mais que texto: trata-se de uma prática através da qual se transforma a história de decadência em um testemunho que "resgata" o valor moral perdido; é, em suma, uma técnica de recuperação - e, certamente, os textos bíblicos fornecem matéria-prima para essa prática.

Com efeito, a rotina do centro de recuperação é fortemente marcada pela prática da palavra. Podemos falar em dois espaços de prática: o formal - os cultos, os momentos de estudo da bíblia, as orações antes das refeições, as orações da madrugada (eles acordam todos os dias às três da manhã para realizar uma oração coletiva) - e o informal - as atividades corriqueiras: o trabalho, o futebol, as conversas cotidianas e os momentos de ócio. É muito comum ver os alunos, em seus momentos de ócio, cantarolando músicas evangélicas, conversando sobre a bíblia, lendo-a ou apenas balbuciando aleluias e glórias a Deus sem motivos maiores.

O culto é um espaço no qual a palavra é praticada nas suas mais variadas formas. Há músicas, pregação dos pastores e dos obreiros, leituras bíblicas, testemunhos. Conforme escutei de muitos obreiros, durante os cultos seria possível medir o grau de recuperação dos alunos observando a forma como eles lidam com a palavra: verificando se eles sabem cantar músicas evangélicas, se escutam atentamente as leituras bíblicas, se se esforçam para decorar algumas passagens, etc. O mesmo ocorre nos outros espaços: aqueles que se negam a realizar as orações quando são solicitados pelos obreiros - como antes das refeições - ou que não se mostram dispostos a realizar as orações da madrugada, dariam indícios claros de que não estão se recuperando.

A presença nos espaços formais de prática da palavra é obrigatória. Muitas vezes escutei dos pastores frases como "aqui a gente não obriga ninguém a ser crente, mas todos têm a obrigação de participar das atividades: se tem culto, tem que ir ao culto; se tem oração de madrugada, tem que levantar para fazer”. Isso é interessante, pois remonta à diferença entre crença e engajamento, que costumam se confundir na ideia mais geral de "conversão" (Teixeira 2013). No centro de recuperação, cobra-se dos alunos o engajamento na palavra e não necessariamente a crença nela. Acreditase que isso pode, inclusive, conduzi-los da descrença à crença - quando o aluno não partilhar da fé cristã pentecostal, evidentemente.

Certo dia, por exemplo, durante o trabalho de campo, um aluno comentou comigo que não gostava de ir aos cultos no início de sua estadia, principalmente quando eram presididos pelo pastor Raimundo, pois este costumava gritar de forma insistente e estridente em suas pregações. Entretanto, o rapaz conta que aos poucos foi percebendo a necessidade de pregações como as de Raimundo, pois só "aos berros" a palavra poderia entrar em pessoas como ele. Este tipo de representação da palavra (como coisa que entra nas pessoas) é perfeitamente condizente com a representação do mal que marca a maior parte das trajetórias das pessoas no sítio: a chamada dependência 
química. Pastor Raimundo costumava dizer cotidianamente que "a cocaína é o Diabo ralado e a cerveja é a pombagira em líquido". Assim, do mesmo modo que o diabo poderia entrar no corpo das pessoas através das drogas - e conduzi-las ao crime, ao vício, às ruas, ao "fundo do poço" -, a palavra também poderia entrar nelas e "libertálas" do mal capaz de fazê-las agir da maneira como agiam.

Já nos espaços informais, a prática da palavra não é obrigatória, embora seja esperada e desejada. Através das conversas cotidianas, por exemplo, seria possível mensurar a "mudança" de cada um. Certa vez, o pastor Raimundo foi bastante explícito quando me disse o que fazia para saber quando alguém estava realmente mudando. Ele contou que prestava atenção nas conversas que os alunos mantinham com os demais. Se antes só falavam das coisas do mundo, de drogas, de crime; agora eles deveriam falar de Deus, ler mais a Bíblia, andar sempre com uma Bíblia na mão, conversar assuntos religiosos com os outros alunos, escutar e cantar músicas evangélicas. Era assim que ele mensurava concretamente a recuperação dos alunos.

Contudo, isso não se encerra em um mecanismo de vigilância operado por pastores e obreiros. A prática da palavra é vivida como uma técnica de recuperação pelos próprios alunos que buscam através dela construir cotidianamente seus testemunhos. Ao ser questionado sobre o que havia sido mais difícil na sua mudança de vida, Cleiton, por exemplo, disse o seguinte:

Meu caráter. Jeito de falar. Os gestos. As gírias. Isso é difícil de morrer. O caráter é o principal. Porque se eu conhecer uma mulher evangélica eu não vou chegar nela falando gíria, igual eu fazia antigamente: "e aí, vamos dar uma volta". Eu não vou chegar e chamar ela de uva, coisa que eu falava quando tava no mundo. Vou ter uma conversa sadia, uma conversa em que Deus trabalha ali e você saiba se explicar, se desenvolver mais. Tem que ser mais educado. Até pra falar com os outros lá no mundo, mesmo sendo cristão você tem que saber falar. Porque qualquer palavra sua errada você está arriscado de tomar um tapa por dentro da sua cara. E é isso que o inimigo vai querer usar. As pessoas que estão lá fora... pra tentar tirar você da benção... que é estar na paz espiritual com Deus, sem problemas...

O manejo da palavra é, de forma geral, o manejo da linguagem: verbal e corporal. Nesse trecho de entrevista, o manejo da palavra aparece como algo importante até mesmo em situações de flerte. As gírias não são pensadas apenas como um dispositivo informal da linguagem; elas resgatariam algo da vida que os lançou na decadência da qual buscam se recuperar. A linguagem acionada seria capaz de fazer com que aquele que fala fosse transportado aos valores e às regras da vida pregressa. De modo geral, errar ou ignorar o manejo da palavra pode "tirar a pessoa da benção", isto é, retirar a pessoa do "estado de dignidade" que a prática da palavra seria capaz de produzir. 
A palavra precisa circular o tempo inteiro pelo sítio e é através do seu manejo que a transformação acontece; ao mesmo tempo, isso é a "transformação" em si. É preciso, então, ouvi-la, lê-la, dizê-la, escutá-la, cantá-la, enfim, testemunhá-la durante todo o tempo. Quanto mais isso acontece, mais se considera que a pessoa se recupera.

Em certa ocasião, durante o café da tarde, eu conversava com alguns alunos sobre a questão do crack. Foi nesse contexto que um deles, chamado Romário, disseme que o crack era uma "fábrica de vacilões". Ele nos contou que, em sua favela, um cracudo havia roubado uma criança e levado cem reais que estavam com ela (o que representa um tipo de crime deplorável, constantemente associado à figura do cracudo). A família deu queixa junto aos traficantes, que decidiram ir atrás do ladrão. Romário começa a se empolgar com a história e passa a falar de modo bastante animado, até bem humorado, com o vigor de alguém que lembra de uma situação saudosa. $\mathrm{E}$ diz: "E aí nós saímos tudo de peça [armas de fogo] atrás dele". Nesse momento ele faz uma pausa repentina, alguns segundos em silêncio que quebram o ritmo da narrativa, e, mudando o tom da performance, dispara: "É, mas isso no passado, né, varão, porque hoje nós somos libertos em nome de Jesus". Então, a partir disso, Romário retoma a história, concluindo que, depois de algumas buscas fracassadas, o ladrão acabara sendo morto pelos bandidos que o encontraram.

De certa forma, o espaço da informalidade também é perigoso para aquele que está em recuperação. As conversas que se desenrolam ali podem ser tomadas como provas positivas ou negativas da transformação de alguém. Romário, que relembrava seus tempos como traficante numa conversa despretensiosa, teve de tomar cuidado com a maneira através da qual acionava a sua memória. E é justamente o manejo da palavra que ressignifica o sentido daquela comunicação: "mas agora estou liberto em nome de Jesus". Essa expressão faz com que a fala de Romário não seja apenas um causo contado entusiasmadamente por um ex-bandido - que poderia ser compreendido como uma prova de que ele ainda estava ligado (afetivamente) ao "mundo do crime" -, e sim o testemunho de sua recuperação - alguém que aciona sua memória e suas experiências anteriores através da palavra. Na construção do testemunho, é a prática da palavra que medeia as conexões possíveis com o "mundo do crime". A "recuperação" não necessariamente aniquila os valores e as experiências do "mundo do crime" - ao contrário, constrói-se em diálogo com eles (Birman e Machado 2011; Teixeira 2011:146-150). No entanto, no centro de recuperação, pastores, obreiros e alunos são capazes de reconhecer as (muitas vezes sutis) diferenças entre um testemunho autêntico e um falso. Na transformação de uma história de decadência em um testemunho considerado autêntico, as conexões com o "mundo do crime" são mediadas pela prática da palavra.

Assim, é importante ressaltar que a prática da palavra não é definida como o recurso a um conteúdo religioso para interagir com os demais. Os conteúdos das conversas e das falas podem variar, obviamente. O que está em questão é a forma como eles são expressos: pastores, obreiros e alunos reconhecem que há formas corretas e 
erradas - e que os limites entre elas não são consensuais nem facilmente definíveis. É aqui que a prática da palavra se torna um recurso importante para produzir e medir a recuperação dos alunos, bem como para a construção de seus testemunhos - pois ela funcionaria como um importante recurso para a mobilização da memória, para a construção das narrativas biográficas, e também como um recurso de interação com os outros, nas mais variadas situações, dentro e fora do sítio. De forma geral, acredito que a prática da palavra pode ser pensada como um mecanismo de ajustamento que regula as rupturas e as continuidades entre a "vida antiga" e a "nova", procurando delimitar um campo de possibilidades (Velho 1994).

\section{Transformando a decadência em testemunho II: a obediência como prova da recuperação}

Quando eu me converti, eu disse pra mim mesmo: não adianta eu aceitar Jesus e eu continuar com os meus vícios - que eu tinha vícios, entendeu, vício de usar cocaína, de usar maconha. Então não adianta eu ficar na igreja e ficar com um pé aqui dentro e outro lá fora. Então decidi ir pra uma casa de tratamento, onde eu fui pra uma casa de recuperação em Tinguá e lá eu fiquei um ano. O propósito lá era ficar nove meses, mas eu fiquei mais que nove meses, eu fiquei mais tempo porque... um rapaz que saiu de uma vida torta é difícil de obedecer, e lá eu obedecia, fazia tudo o que tinha que fazer. Entrei como aluno e lá mesmo eu passei a tomar conta dos alunos. E quando eu saí de lá foi só vitória.

A obediência, assim como a palavra, é considerada como importante indicador de recuperação e de produção de testemunho. Assim, acatar as ordens dadas pelos pastores e pelos obreiros, respeitar as normas da casa, como os códigos de vestuário, estar presente nos cultos e nas orações, trabalhar nas tarefas que forem designadas, dentre outras coisas, são consideradas posturas de extrema importância para a avaliação da recuperação dos alunos. Obedecer aos superiores e às regras estipuladas é considerado algo fundamental no processo de construção do testemunho e de engajamento na "vida evangélica" experimentados no centro de recuperação. Em entrevista com Miguel, um aluno, ele sublinha:

Deus só te manda obedecer. É difícil. Mas obedecendo você é um outro homem. Meu único caminho é Jesus, mais nada. Só tenho que olhar pra frente e não olhar pro lado. Você ajoelhar, como a gente faz aqui nesse centro de recuperação. Como hoje, depois do almoço, ajoelhei, pedi, eu sei que eu vou ter minha resposta. De madrugada, acordar às três da manhã, orar, todo dia a gente vive de oração. Oração pra lá, oração pra cá. Fora as tribulações que a gente passa aqui com os irmãos, que 
Satanás joga seta aqui dentro da gente, pra gente se atribular e jogar nós lá na rua. A gente é de carne né, mas a gente tem que matar essa carne.

A obediência é vista pelos alunos como uma forma de anular - ainda que precariamente - as ações nas quais eles reconhecem a "vulnerabilidade espiritual" que seria a responsável por suas trajetórias de decadência moral. Nesse sentido, obedecer seria experimentado como uma forma bastante peculiar de despossessão (Butler e Athanasiou 2013): a obediência seria vivida como uma forma de despossuir-se de si mesmo - do "si mesmo" considerado responsável pela trajetória decadente -, reconhecendo, no entanto, no acatamento da autoridade exercida pelo outro, parte fundamental da possibilidade de sua reconstrução - no caso do centro, de sua "recuperação". Porém, a experiência da obediência não é algo que possui uma lógica alheia ao contexto que enreda as histórias de vida que povoam o centro de recuperação; é uma prática que está diretamente vinculada às categorias e aos valores associados, por alunos, obreiros e pastores, ao "mundo do crime".

Em minhas conversas com o pastor Vladimir, sempre ouvia, por exemplo, que os "bandidos de verdade" (termo que ele às vezes utilizava para diferenciá-los daquelas pessoas que passaram pelo "mundo do crime" mas saíram como vacilões) eram os mais obedientes. Ele sublinhava que esses bandidos estavam acostumados com regras, hierarquias e obediência e que essa bagagem que traziam do "mundo do crime" funcionava como algo duplamente positivo: para suas próprias recuperações e para a manutenção da ordem no local. Assim, ao me dizer como os "bandidos de verdade" eram mais dóceis que os "vacilóes", o pastor Vladimir chamava a atenção para uma série de continuidades possíveis entre a "vida no crime" e a "vida no evangelho" que estruturam uma hierarquia dos ex (Corrêa 2015) - na qual esses bandidos estariam no topo. Mas, do ponto de vista do pastor, essa continuidade aparece em um plano muito genérico. Operar com ela é uma atividade muito mais complexa. Vejamos.

A partir do décimo quinto dia no sítio, os alunos ganham o direito de telefonar para seus parentes. Nessas ocasiões, os obreiros os acompanham, dividindo-os em diversos grupos para irem caminhando até o telefone público mais próximo do sítio que fica cerca de um quilômetro do local. A função dos obreiros é justamente vigiar a conversa dos alunos: verificar para quem ligam, que tipo de conversa têm, como conversam, se falam da bíblia e das coisas de Deus, etc. Em situações como essa, uma série de conflitos internos surgem. Chamava bastante atenção o fato de que pessoas que haviam sido ligadas a facções criminosas diferentes convivessem no mesmo local sem que essas diferenças viessem à tona como um problema. Na maior parte das vezes, diziam que agora as facções não faziam mais sentido, pois todos pertenceriam a uma mesma facção: "Jesus". No entanto, a rotina do sítio fazia com que outras marcas da sociabilidade no "mundo do crime" fossem acionadas, como o incômodo em ser vigiado por um obreiro ex-vacilão, isto é, por alguém que no sítio se encontra em uma situação de mando mas, ao mesmo tempo, possui uma trajetória de "decadên- 
cia" singular. Contudo, esses incômodos não se transformavam em conflitos maiores desde que o obreiro soubesse exercer o seu poder de mando sem comprometer seu testemunho. Se o obreiro utilizasse uma linguagem comum para exercer o seu poder de mando, fazendo uso de gírias e de outros elementos identificados como próximos ao "mundo do crime", demonstrava, com isso, que estava mobilizando recursos da "vida no crime" - na qual fora, anteriormente, um vacilão. Ou seja, a linguagem poderia acionar as hierarquias do "mundo do crime". Quando o obreiro recorria a uma linguagem evangélica, isso era interpretado pelos ex-bandidos como algo que compensava a trajetória como vacilão, já que funcionava como testemunho: uma prova real de sua recuperação. Ao mesmo tempo, legitimava a reconfiguração dos códigos: não se estaria obedecendo a um vacilão, mas a alguém que teria sido liberto do mal através da palavra, a um servo de Deus. Desse modo, a palavra funciona, ainda, como uma prática capaz de reorganizar as hierarquias do "mundo do crime", estruturando e legitimando novas relações de mando e obediência na rotina do sítio. Portanto, vive o testemunho quem sabe obedecer, mas o reconhecimento da autoridade moral também depende do testemunho de quem a exerce.

Isso faz com o que o centro de recuperação seja um lugar com grandes potenciais de conflito. O futebol, por exemplo, talvez seja o espaço de sociabilidade considerado o mais perigoso da rotina do centro - e onde a prática da palavra e da obediência se tornam mais vulneráveis. Nele, os alunos quase sempre mobilizam as diversas marcas identitárias que compõem suas trajetórias. Como é um espaço no qual a jocosidade é reconhecida como legítima, as interações tendem a ser menos rígidas. E, exatamente por essa razão, o futebol é visto por muitos alunos como um dos espaços mais perigosos da rotina do centro de recuperação, pois nele os atores podem "perder a benção", "sair da graça" ou "sair da presença de Deus" - expressões utilizadas para descrever aqueles que deliberadamente (e momentaneamente) decidem desengajar-se da "vida evangélica", apelando para as habilidades (violência física) e para as linguagens (gírias, palavrões) que caracterizariam suas vidas no crime.

Em todas as vezes em que assisti aos jogos havia uma situação clássica da "pelada" ${ }^{\prime}$ : mais jogadores do que o que cabe em dois times, o que obriga a uma organização de revezamento dos times no sistema dez minutos ou dois gols. Enquanto uma partida acontece, os demais jogadores ficam na beira no campo esperando a próxima. Aqueles que ficam do lado de fora descansam, assistem ao jogo e, principalmente, "zoam" quem está jogando. O tipo social que ocupa a beira do gramado é certamente aquele com o maior potencial de gerar as situações de perigo que fazem com que os alunos temam "sair da presença de Deus". O "zoador" é aquele que fica o tempo todo rindo dos erros dos outros e comentando jocosamente o jogo. Nas "peladas" do sítio sempre havia diversos "zoadores". E percebi que a maioria deles concentrava suas tiradas jocosas nos obreiros que estavam jogando. Esta era uma situação em que os alunos aproveitavam, por exemplo, para reconstruir momentaneamente as hierarquias: "zoando" aqueles que representavam a autoridade sobre eles no cotidiano do sítio. 
Em um certo jogo, os rapazes na beira do campo "zoavam" muito um obreiro em particular, Mário Lúcio, pois este estava sempre com a roupa limpa (e o campo quase sempre estava um lamaçal só). Enquanto assistia a uma das partidas, um dos alunos me disse que queria muito vê-lo cair no chão, pois naquele dia Mário Lúcio havia chamado injustamente a sua atenção diversas vezes. Como no futebol os critérios de autoridade eram outros, a prática esportiva funcionava como uma válvula de escape para as tensões cotidianas oriundas das complexas relações de mando e obediência que configuravam a vida no sítio.

Contudo, ao observar algumas "peladas" no centro de recuperação, pude perceber o quanto os conflitos experimentados no futebol articulavam a "vida antiga" e a "vida nova", reconstruindo momentaneamente as hierarquias do grupo mas também produzindo uma série de perigos morais para a vida no sítio, sendo o mais notável o risco de a zoação desdobrar-se em algum episódio de violência física. Em certos casos, o tombo moral (Werneck 2015) produzido pela zoação pode ser considerado tão grave que uma mudança no padrão da interação pode ocorrer, quando então a crítica e o conflito verbal se transformariam em confronto físico. As brigas são punidas pelo pastor com a expulsão imediata do centro. Mas, igualmente para os alunos, recorrer à violência física significa dar uma prova negativa de sua "recuperação", significa "sair da graça", "sair da benção" ou "sair da presença de Deus". Como na metáfora do cobertor curto, manter a "dignidade" atingida pela zoação através de agressões físicas e verbais compromete a "dignidade" recuperada através da palavra e da obediência.

Como o campo não possuía marcações (área do goleiro, laterais, linhas de fundo), o juiz tinha muitas dificuldades para apitar os jogos. Mas, na verdade, por mais que houvesse juízes (alguns alunos se revezavam nessa função), eles quase não tinham autoridade nas partidas e, frequentemente, tornavam-se objeto de "zoação" dos outros - diziam que o juiz só servia para pendurar o apito no pescoço. Na maior parte dos lances, os próprios jogadores decidiam, por exemplo, se uma jogada havia sido faltosa ou não, ou de quem era a posse da bola após ela sair de campo. Sem as marcas do campo, as autoridades e os julgamentos precisavam ser negociados a todo momento. $\mathrm{O}$ juiz realmente era apenas parte do cenário e só marcava o que era claro e indiscutível. O que precisava de fato de uma autoridade para ser decidido era, na prática, discutido coletivamente, com negociação. No entanto, a necessidade de negociar os lances também fazia com que as situações de tensão e de perigo surgissem com mais frequência.

Conversei com muitos alunos que se recusavam a jogar futebol, argumentando que as partidas eram perigosas, já que pessoas que não se davam bem na rotina do sítio poderiam ficar em times diferentes, podendo gerar desentendimentos e até mesmo brigas. Miguel, ex-bandido, contou-me que na época em que estava no crime jogava no time da "boca". E comentou: "os únicos que jogavam de igual para igual com os bandidos eram os crias". Conforme a conversa prosseguia, compreendi que com isso ele queria dizer que os "crias" eram os únicos autorizados a jogar sem medo de desagradar os bandidos durante a partida: cometiam faltas duras e reclamavam do time 
da boca constantemente, além de serem considerados os únicos que poderiam "zoar" os bandidos (fazer comentários jocosos a respeito de suas atuações em campo). Neste caso, o futebol reforçava as hierarquias locais: de um lado, os bandidos, com sua força bélica e sua disposição para utilizá-la; do outro, os crias, com a força moral atribuída àqueles moradores cujas famílias estão há gerações na favela. Nesta situação, o futebol era razoavelmente seguro. No sítio, o futebol quase sempre atingia as hierarquias locais e, por isso mesmo, era fonte de perigos morais. Miguel também me disse que só voltaria a jogar quando realmente estivesse recuperado: quando ele se sentisse seguro para arriscar-se a atuar nesses espaços de sociabilidade sem correr o risco de "sair da benção", quando se sentisse pronto para "viver seu testemunho dentro de campo".

\section{Dar o testemunho: sinceridade e compromisso}

O ato de testemunhar, de dar ou contar o seu testemunho a alguma audiência, é compreendido como algo que não pode ser realizado sem sinceridade. Evidentemente, isso não significa que os atores do centro de recuperação ignorem a possibilidade de falsos testemunhos. No entanto, mais do que assegurar uma correlação entre o conteúdo da fala e os fatos da vida, alunos, obreiros e pastores reconhecem que dar um testemunho sincero implica, sobretudo, comprometer-se com a narrativa construída. Por um lado, as histórias de superação e de transformação são consideradas fonte de tanto valor que era muito comum escutar das lideranças que muitos alunos contavam "até o que jamais haviam feito", apenas para desfrutar do prestígio gerado pelo testemunho em sua dimensão performativa. Porém, mentiras como dizer que matou diversas pessoas quando na verdade nunca o fez, ou dizer que comeu comida do lixo quando isso nunca ocorreu, não eram consideradas erros tão graves na construção do testemunho. De certa forma, essas mentiras não atingiam a sinceridade do testemunho - ou o faziam de forma muito irrelevante. A sinceridade era cobrada como compromisso com a narrativa construída. Era necessário, então, dar provas da mudança de vida e da transformação de si narradas na performance do testemunho. Por esta razão, dar o testemunho nos espaços formais de prática da palavra, por exemplo, torna-se um momento importante do processo de recuperação, no qual se espera que o aluno, ao contar sua narrativa aos demais, comprometa-se com ela. Nesse sentido, ser escolhido pelas lideranças para dar o testemunho em cultos e outros espaços formais de prática da palavra significaria, a priori, um fortíssimo indício da recuperação de alguém. Não por acaso, no início da pesquisa, era muito comum que o próprio pastor Vladimir escolhesse os entrevistados, pois julgava que nem todos tinham condições de dar seu testemunho. Há, de certa forma, o pressuposto de que quem testemunha, sobretudo em performances públicas, se compromete: consigo, com sua audiência e com Deus.

Jair, um dos alunos, durante uma entrevista, disse-me que, diante de testemunhos falsos (de pessoas que testemunham mas não se comprometem com o teste- 
munho), as coisas poderiam piorar, pois Deus "abominava a traição". Ou seja, falsos testemunhos poderiam recolocar os atores em trajetórias de decadência, uma vez que isso representaria uma quebra do compromisso estabelecido com o próprio Deus. Jair conta a história de alguns amigos que se converteram na cadeia, mas, logo depois, retornaram ao crime e acabaram morrendo.

Aí eu falei pra eles: olha, vocês vão aceitar Jesus sim, mas lá fora seja homem de Deus, ou sai ou fica. Se a gente for falso com Deus, ele abomina. Eu aceitei Jesus aqui, Deus te deu a liberdade de você trabalhar pra ele, pra você chegar lá fora e abandonar o caminho, já seguir o caminho do mal. Quem está lá no mal está doido pra te pegar. A tua briga não é contra o ser humano, a tua briga é contra potestades malignas. Então, o mole que você der você vai morrer. Saíram, não podiam pegar dinheiro na boca, mas mesmo assim ainda pegaram dinheiro na boca porque ainda tinham moral com uns moleques lá e quando foi quinze dias depois foram me falar: ó, fulano de tal e fulano de tal acabaram de cair [ser mortos]. Cara... Por quê? Traíram Deus. Procuraram o caminho do mal de novo e esse é um caminho que eu não quero mais não.

O que Jair apresenta como "caminho do mal" não diz respeito apenas ao retorno ao tráfico. O retorno ao mal é, sobretudo, o retorno à decadência moral, representada pela traição (ato abominável tanto por Deus quanto pelos bandidos). É extremamente interessante observar como, através da "traição" e da "desobediência", a "vida do crime" e a "vida evangélica" se unem para compor uma única e coesa narrativa. Para Jair, a traição a Deus estava diretamente relacionada a um castigo aplicado a uma desobediência na "vida do crime". Se eles não houvessem traído Deus com seu falso testemunho e tivessem se engajado com sinceridade na "vida evangélica", aposta Jair, certamente seriam pessoas obedientes e dificilmente, portanto, estariam sujeitos a punições por atitudes como essas, no "mundo do crime".

Dias (2008), por exemplo, em sua análise de conversões de detentos ao pentecostalismo no sistema penitenciário paulista, também destaca que os conversos, para serem considerados pelos detentos como "crentes autênticos", fora do alcance de várias dinâmicas de violência que atravessam o cotidiano prisional, deveriam demonstrar publicamente sua "transformação", comprometendo-se com seu testemunho e com sua mudança, sob o risco de serem vistos pelos demais como alguém que apenas estaria "se escondendo atrás da bíblia". E, vale ressaltar, isso seria algo compartilhado por evangélicos e demais detentos.

Por outro lado, o testemunho considerado sincero também produz implicações importantes. Na maior parte dos casos, a "recuperação autêntica" é capaz de conferir ao ator o reconhecimento de valor e de autoridade moral que lhe permitem acessos e circulações que de outro modo talvez não fosse possível. No centro de recuperação, 
por exemplo, muitos alunos sonhavam com o dia em que retornariam às suas favelas para pregar aos traficantes (que ou foram seus parceiros, seus superiores, ou mesmo seus algozes). Muitos costumavam descrever aquilo que imaginavam como "o grande retorno": um episódio no qual exibiriam a sua "volta por cima", performatizando poderosamente o seu testemunho em igrejas e praças lotadas. Imaginavam um retorno triunfal, em que pregariam e contariam seus testemunhos para amigos e inimigos, advertindo-os a abandonarem o crime e seguirem Jesus. E, em muitas ocasiões, isto realmente acontecia: a "transformação de si" conferia ao converso uma autoridade moral sobre traficantes e outros personagens considerados violentos e perigosos: submeter-se ao "santo", àquele que dá testemunho autêntico, não seria visto como um rebaixamento moral.

De acordo com Mafra (2014), sinceridade e santidade poderiam ser pensadas como duas "ideologias semióticas" (Keane 2002) que atravessariam, de forma tensa e contínua, a construção social da pessoa no pentecostalismo brasileiro. Enquanto a sinceridade estaria ligada à tradição protestante calvinista, a santidade estaria ligada à tradição católica. Segundo Mafra (2014:175):

Sinais deste "conflito semiótico" apareceram em meu trabalho de campo, quando, por exemplo, meus interlocutores pentecostais alegavam que, em face de questões morais espinhosas, seria essencial ouvir aquilo que "o coração diz". Esta afirmação está em plena sintonia com a "ideologia da sinceridade", ou seja, com a necessidade dos enunciantes escrutinarem suas próprias palavras, organizando-as e combinando-as em adequação às suas intenções e seus pensamentos. Porém, este processo de auto-avaliação era frequentemente interrompido (ou prolongado) pela subordinação dos oradores a lógicas de aproximação ou distanciamento de lugares, pessoas e coisas santas ou demoníacas. Aqui também se pode identificar uma dualidade ou conflito entre as premissas da "ideologia de sinceridade" e aquilo que chamarei de uma "ideologia de santidade" no interior do pentecostalismo.

Assim, se, por um lado, a sinceridade, enquanto "ideologia semiótica", pressupõe um campo de fala e de ação na qual os atores podem agir livremente, conforme suas próprias convicções, escutando o "próprio coração", por outro, a santidade pressuporia um campo de fala e de ação no qual os atores teriam que levar em consideração lógicas de aproximação e afastamento que estão para além do que vem de "seu interior". A sinceridade e o compromisso demandados na construção do testemunho no centro de recuperação parecem ser atravessados por essas tensões entre a ideologia da sinceridade e a da santidade. A construção do testemunho sincero produz o "santo", aquele que poderá desfrutar do reconhecimento de uma autoridade moral. Em contrapartida, seria justamente essa santidade que permitiria aos atores desfru- 
tarem de uma maior autonomia e liberdade de ação - agindo conforme seu próprio "coração" - em contextos nos quais, anteriormente, eles não poderiam, devido à sua condição de decadência moral.

É muito comum que pastores e obreiros ligados a centros de recuperação gozem de reconhecimento e respeito junto a traficantes e milicianos. Esses pentecostais conseguem negociar a liberdade de vacilões capturados e prestes a ser assassinados, mediante a promessa de os conduzirem aos seus centros e os recuperarem. Em boa parte das vezes, os pastores são chamados pelos próprios bandidos para resgatar essas pessoas marcadas para morrer. Em uma conversa com um pastor ex-bandido que trabalha em outra instituição, mas que circulava por vários locais ocupados por traficantes e milicianos à procura de pessoas para resgatar, ouvi o seguinte: "a minha santidade é o que garante a minha segurança quando eu subo as favelas para resgatar as pessoas da morte". O pastor me falava o quanto era importante que ele vivesse seu testemunho de forma sempre sincera e o quanto, no seu caso em especial, a vigilância sobre si mesmo deveria ser mais rigorosa. Ele dizia que os bandidos só o respeitavam porque viam coerência entre o seu testemunho e a sua vida. "Eles observam", dizia o pastor, "que eu não saio por aí com mulheres, que eu não bebo, não uso drogas, que eu não falo gírias e palavrões, que tenho uma vida no Senhor". Neste caso, portanto, sinceridade e santidade articulam-se fortemente - a santidade seria produto de um testemunho sincero -, potencializando a autoridade moral do pastor. Este, bastante ciente de sua situação, dizia abertamente que sua relação com os bandidos - uma relação de autoridade moral que lhe permitia interferir diretamente em várias dimensões do cotidiano do movimento, inacessíveis a outros atores e a outros coletivos - era algo que agregava muito valor à sua trajetória - o que, inclusive, havia lhe rendido um bom emprego em uma $O N G$ que possuía um projeto de mediação de conflitos em áreas ocupadas por narcotraficantes.

\section{Considerações finais}

Sugiro, como hipótese, que a produção de valor moral passa pelo domínio de uma gramática do testemunho na qual diferentes dimensões dessa prática (ter, dar e ser testemunho) precisam ser articuladas de modos específicos pelos atores para que o testemunho seja reconhecido como autêntico. Tomando como referência a filosofia do chamado segundo Wittgenstein (2011), explorar o testemunho em um enquadramento gramatical implicaria, então, trazer à análise seus diferentes usos, mobilizados em diversos contextos e situações, os quais produzem distintos significados. Nesse sentido, a perspectiva gramatical ajudaria a nos descolar um pouco da centralidade do conteúdo da narrativa biográfica, proporcionando uma espécie de visão panorâmica do testemunho.

No contexto do centro de recuperação, a prática do testemunho não se esgota em seu conteúdo autobiográfico, embora esta seja sua dimensão mais proeminente. 
De forma geral, o testemunho parece definir-se também por representar um tipo de forma social capaz de produzir valor moral, na qual se articulam a construção de uma narrativa, sua performance e a sustentação do seu conteúdo nas interações cotidianas. Como vimos, nesse contexto, a dimensão performativa do testemunho não pode ser pensada de forma isolada, pois ela estaria completamente atravessada pelas relações, interações e situações que compõem o cotidiano do centro de recuperação. Desse modo, não bastaria ter um testemunho para contar; é necessário sê-lo, isto é, comprometer-se com a própria narrativa construída, dando provas de que a "transformação de si" é uma prática cotidiana, para que sua performance seja considerada autêntica e produza a valorização moral da pessoa. Saber operar com essa gramática é fundamental nos processos de recuperação operados no centro, tanto para os alunos quanto para os pastores e para os obreiros. No entanto, os dados etnográficos também indicam que essa gramática é amplamente compartilhada, para além do contexto estudado, e que ela estaria em alguma medida associada à autoridade moral da qual muitos evangélicos desfrutam em contextos marcados pela presença do narcotráfico varejista e das milícias.

\section{Referências Bibliográficas}

BIRMAN, Patricia. (2009), "Feitiçaria, resistência e territórios marginais". Mana, vol. 15, n 2: 321-348. BIRMAN, Patricia e MACHADO, Carly. (2011), "A violência dos justos: evangélicos, mídia e periferias da metrópole". RBCS, vol. 27, n 80: 55-69.

BUTLER, Judith and ATHANASIOU, Athena. (2013), Dispossession: the performative in the political. Cambridge: Polity Press.

CASTEL, Robert. (1997), "As dinâmicas do processo de marginalização: da vulnerabilidade à 'desfiliação”. CADERNO CRH, n 26/27: 19-40.

CORREAA, Diogo. (2015), Anjos de Fuzil: Uma Etnografia da Relação entre Igreja e Tráfico na Cidade de Deus. Rio de Janeiro: Tese de Doutorado em Sociologia, UERJ.

DAS, Veena. (2007), Life and words: violence and the descent into the ordinary. California: University of California Press. . (2011), "O ato de testemunhar: violência, gênero e subjetividade". Cad. Pagu, n 37: 9-41.

DIAS, Camila. (2008), A Igreja como Refúgio e a Bíblia como Esconderijo: Religião e Violência na Prisão. São Paulo: Humanitas.

DULLO, Eduardo. (2011), "Uma pedagogia da exemplaridade: a dádiva cristã como gratuidade”. Religião $\mathcal{G}$ Sociedade, vol. 31, n 2: 105-129.

. (2013), A produção de subjetividades democráticas e a formação do secular no Brasil a partir da pedagogia de Paulo Freire. Rio de Janeiro: Tese de Doutorado em Antropologia Social, PPGAS/MN/ UFRJ.

FREITAS, Amílcar. (2016), E isso é bandido? Engajamentos à vida do crime na região metropolitana da Grande Vitória. Rio de Janeiro: Tese de Doutorado em Ciências Humanas (Sociologia), PPGSA/ IFCS/UFRJ.

GRILLO, Carolina. (2013), Coisas da vida no crime: tráfico e roubo em favelas cariocas. Rio de Janeiro: Tese de Doutorado em Ciências Humanas (Antropologia Cultural), PPGSA/IFCS/UFRJ.

KEANE, Webb. (2002), "Sincerity, 'Modernity' and the Protestants”. Cultural Anthropology, vol. 17, n 1: 65-92. 
MACHADO, Carly. (2014), "Pentecostalismo e o sofrimento do (ex-)bandido: testemunhos, mediações, modos de subjetivação e projetos de cidadania nas periferias". Horizontes Antropológicos, ano 20, $n^{\circ} 42: 153-180$.

MAFRA, Clara. (2014), "Santidade e sinceridade na formação da pessoa cristã". Religião $\mathcal{E}$ Sociedade, vol. 34, n 1: 173-192.

RIBEIRO, Fernanda Mendes Lages e MINAYO, Maria Cecília de Souza. (2015), "As comunidades terapêuticas religiosas na recuperação de dependentes de drogas: o caso de Manguinhos, RJ, Brasil". Interface, vol. 19, $\mathrm{n}^{\circ}$ 54: 515-526.

SELIGMANN-SILVA, Márcio. (2008), "Narrar o trauma: a questão dos testemunhos de catástrofes históricas". Psicol. clin., vol. 20, n¹: 65-82.

. (2010), "O local do testemunho". Tempo e Argumento - Revista do Programa de Pós-Graduação em História, vol. 2, n 1: 3-20.

TEIXEIRA, Cesar Pinheiro. (2011), A construção social do "ex-bandido": um estudo sobre sujeição criminal e pentecostalismo. Rio de Janeiro: 7Letras.

. (2013), A teia do bandido: um estudo sobre bandidos, policiais, evangélicos e agentes sociais. Rio de Janeiro: Tese de Doutorado em Ciências Humanas (Sociologia), PPGSA/IFCS/UFRJ.

VELHO, Gilberto. (1994), Projeto e Metamorfose. Rio de Janeiro: Zahar.

WERNECK, Alexandre. (2015), “'Dar uma Zoada', 'Botar a Maior Marra': Dispositivos Morais de Jocosidade como Formas de Efetivação e sua Relação com a Crítica”. Dados, vol. 58, n 1: 187-222.

WITTGENSTEIN, Ludwig. (2011), Investigações Filosóficas. Lisboa: Fundação Calouste Gulbenkian.

\section{Notas}

1 Para ajudar a preservar o anonimato das pessoas, optei por não utilizar seus verdadeiros nomes. Também por essa razão, optei por não indicar a data referente a cada trecho de entrevista. Todas as entrevistas foram realizadas ao longo do ano de 2011.

2 Esse tipo de análise do testemunho é comumente realizado por diversos autores - inclusive por mim (Teixeira 2011). Seligmann-Silva $(2008,2010)$ e Das $(2007,2011)$ constituem exemplos constantemente citados.

3 Ao longo de todo o ano de 2011, no contexto da pesquisa que desenvolvi no doutorado, fiz entrevistas com diversos alunos do centro, bem como com obreiros e pastores. Além disso, acompanhei o cotidiano do centro de recuperação, visitando-o semanalmente.

4 É importante ressaltar que, em minha opinião, o conceito de desfiliação não é adequado para se pensar a situação do morador de rua, já que os moradores de rua constroem laços sociais entre si, organizando-se em grupos cujo tamanho e complexidade variam, obviamente, caso a caso. No entanto, da perspectiva do próprio Castel, é possível dizer que o morador de rua é um desfiliado, considerando que seu conceito está diretamente ligado aos laços sociais associados ao mundo do trabalho formal e a outras formas de filiação que os círculos sociais da rua não abrangeriam. Mas, no centro de recuperação, as representações acerca do morador de rua estão mais próximas de Castel do que de uma perspectiva antropológica relativista. É por esse motivo que eu o mobilizo.

5 Termo comumente utilizado para se referir ao narcotráfico varejista praticado em favelas e periferias do Rio de Janeiro.

6 Este caso difere de outras comunidades terapêuticas religiosas, como as analisadas por Ribeiro e Minayo (2015), que contam com a presença de psicólogos, assistentes sociais, entre outros profissionais.

7 "Pelada" é uma expressão bastante popular no Rio de Janeiro para designar a prática do futebol amador. Mas, no Brasil, existem muitas variações, como, por exemplo, "rachão" e "baba".

Recebido em abril de 2016. Aprovado em maio de 2016. 
Cesar Pinheiro Teixeira (cesarpinheiroteixeira@gmail.com) Bolsista de Pós-Doutorado da FAPERJ vinculado ao Núcleo de Estudos da Cidadania, Conflito e Violência Urbana (NECVU/IFCS/UFRJ). Doutor em Ciências Humanas (Sociologia) pelo Programa de Pós-Graduação em Sociologia e Antropologia do Instituto de Filosofia e Ciências Sociais da Universidade Federal do Rio de Janeiro (PPGSA/IFCS/UFRJ). É autor de A construção social do "ex-bandido": um estudo sobre sujeição criminal e pentecostalismo (7Letras, 2011). 


\section{Resumo:}

\section{O testemunho e a produção de valor moral: observações etnográficas sobre um centro de recuperação evangélico}

O presente artigo procura discutir o testemunho como uma prática densa capaz de agregar valor moral a pessoas socialmente desacreditadas. Essa discussão é realizada a partir de uma pesquisa sobre um centro de recuperação evangélico, situado na periferia da região metropolitana do estado do Rio de Janeiro. Argumenta-se que o testemunho é uma prática que, além da elaboração de si através de uma narrativa biográfica ("ter testemunho"), performatizada em diversas situações ("dar testemunho"), também é composta por um exercício de elaboração de si que se constrói na vida cotidiana de forma relacional ("ser testemunho"). Encerro propondo a hipótese de que a articulação entre essas distintas dimensões do testemunho produz uma gramática própria capaz de agregar valor moral aos atores que a mobilizam.

Palavras-chave: testemunho, comunidades terapêuticas, pentecostalismo, violência urbana, moral.

\section{Abstract:}

Testimony and production of moral value: ethnographic observations on an evangelical recovery center

This paper discusses the testimony as a dense practice, crossed by several meanings, and capable of adding moral value to people socially discredited. This discussion is conducted from a research about a center of evangelical recovery, situated in outskirts of the metropolitan region of the state of Rio de Janeiro. It is argued that the witness is a practice that, in addition to preparing themselves through an autobiographical narrative ("to have a testimony"), performed in various situations ("to give a testimony"), is also composed of an exercise in preparing itself which is built, relationally, in everyday life ("to be a testimony"). The link between these different dimensions of the testimony produces its own grammar capable of adding value to moral actors to mobilize.

Keywords: testimony, drug rehab centers, Pentecostalism, urban violence, moral. 